\title{
Factors of the Extinction of Traditional Knowledge in Minangkabau's Rumah Gadang Carved
}

\author{
Armilia Riza, Aziwarti, Mayuasti, and Surya Prahara
}

STKIP PGRI Sumatera Barat

\section{Abstract}

Rumah Gadang's carved is one of art that lives in the walls of Minangkabau's Rumah Gadang. That carved is inspired by the name of plant, animals, and things that are used in Minangkabaunese daily activity. Every carved has meaning as the traditional knowledge which reflects nature and Minangkabau people daily life. However, this art is nearly disappeared. It makes the existential of traditional knowledge of Rumah Gadang's carved is extinct. The aim of this research is to analyze some factors that cause the extinction of traditional knowledge of Rumah Gadang's carved. The method

Corresponding Author:

Armilia Riza

rizaridwan23@gmail.com

Received: 23 January 2019

Accepted: 26 February 2019

Published: 17 March 2019

Publishing services provided by Knowledge E

(c) Armilia Riza et al. This article

is distributed under the terms of

the Creative Commons

Attribution License, which

permits unrestricted use and

redistribution provided that the

original author and source are credited.

Selection and Peer-review unde the responsibility of the International Seminar on Language, Education, and Culture Conference Committee.

\section{G OPEN ACCESS} of this research is qualitative design. The informants are taken by purposive sampling and located in the center of the Minangkabau carved development zones such as Kabupaten Agam, Tanah Datar, and Lima Puluh Kota. The findings of this research show that the development of modern people's views eliminates the value of a culture, so it is hard to protect. Furthermore, there are some commercial carved industries that produce the replica of Rumah Gadang's carved without understanding the philosophy and the traditional knowledge of the carved. Moreover, the government's efforts to conserve the culture value are not optimal. At last, the portion of law product from Local to National Government Regulations to guarantee the preservation of regional culture is small.

Keywords: factors of extinction, traditional knowledge, Minangkabau's Rumah Gadang carved

\section{Introduction}

The carving art of Rumah Gadang is one of arts which is used in building Rumah Gadang in Minangkabau. the shaping carve is inspired by the nature that is divided into three types. The first type is the carve that is from plants such as Aka Barayun, Aka Duo Gagang, Aka Taranang, Bungo Anau, Buah Anau, Bungo Taratai dalam Aie, Daun Puluik-puluik, Daun Bodi jo Kipeh Cino,Kaluak Paku Kacang Balimbiang, Siriah Gadang dan Siriah Naiak. Second, its name is taken from the animal such as Ayam Mancotok dalam Kandang, Bada Mudiak, Gajah Badorong, Harimau dalam Parangkok, Itiak Pulang Patang, Kuciang lalok, Kijang Balari dalam Ransang and Tupai Managun. Last, 
the carve which is inspired by things that are used in the daily life such as Ambun Dewi, Aie Bapesong, Ati-ati, Carano Kanso, Jalo Taserak, Jarektakambang, Jambua Cewek Rang Pitalah, Kaluak Baralun, Lapiah Duo, Limpapeh, Kipeh Cino and Sajamba Makan. Those inspirations become an important element in creating Minangkabau's culture.

Every shape of carve has meaning that is the symbol of Minangkabaunese life. There are 38 shapes of carve that are identified and usually used. For example, one of the shapes is kaluak paku kacang balimbiang that is drawn like propagating ferns complete with leaves and flower. It is curved like a circle in line, coincide, interwoven and also connect. Branch or root branch cuddle outward, inward, upward and downward. Traditional knowledge attached to this carving motif is in the form of meaning and folklore, the meaning is fennel plant is a daily food of Minangkabau society, while the folklore depicted is "Kaluak paku kacang balimbiang, tampuruang lengganglenggangkan, baok manurun ka Saruaso, tanam sirieh jo ureknyo, Anak dipangku kamanakan dibimbiang, urang kampuang dipatenggangkan, tenggang nagari jan binaso, tenggang saratojo adatnyo". The folklore represents the responsibility of a Minangkabau man who has two functions, as the father of his children and as the mamak (an uncle) of his nephews and nieces. He must guide and educate his children and nephews / nieces to become a useful and responsible person to the families of the people (tribe) and nagari (village).

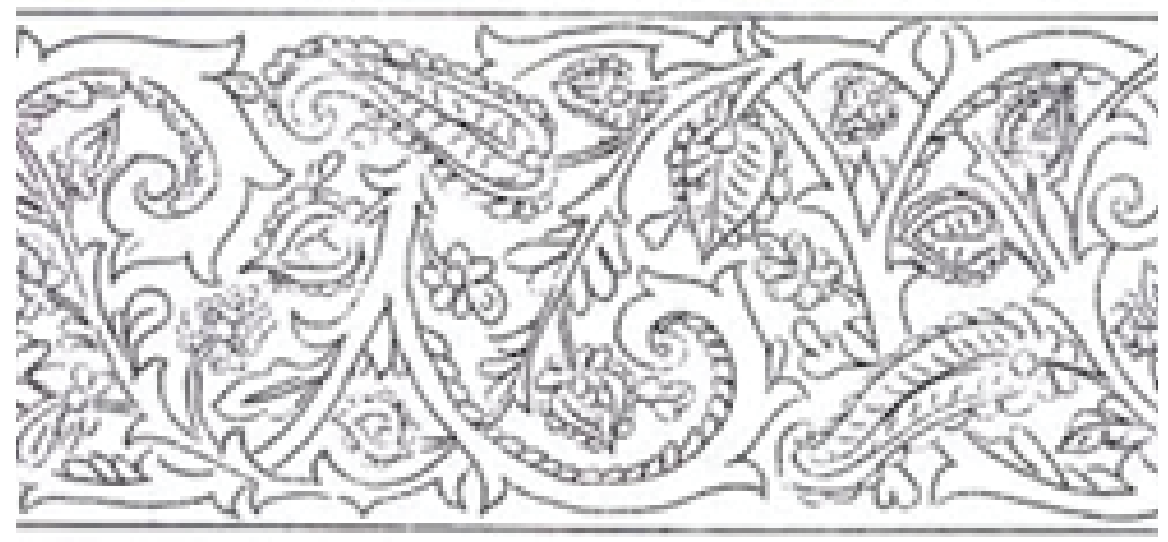

Figure 1: The shape of Kaluak Paku Kacang Balimbiang.

Besides the meaning of each shape, where the shapes must be put on the Rumah Gadang's walls also has traditional knowledge. For example, there is another shape that is called Kuciang lalok jo saik galamai (the Sleeping cat and the cut galamai). This shape means the laziness of cats. It gives warn to the Minangkabau young generation not to be lazy. They have to work hard to give better life to their families. The shape must be put in Rumah Gadang's gonjong (before the top of the roof). Why? It is because cats 
usually sleep there. The purpose of putting the shape there is that the young man can see the shape from far away, so the always remember the meaning had by the shape.

However, the problem is the extinction of Minangkabau's Rumah Gadang carved. It is happen because the small number of Rumah Gadang exists. It can be proven by following data gotten from 12 cities in West Sumatera:

TABLE 1: The Number of Rumah Gadang in West Sumatera.

\begin{tabular}{l|l|l|l|l|l|}
\multicolumn{2}{c|}{ Kabupaten Agam (luhak Agam) } & \multicolumn{2}{c|}{$\begin{array}{c}\text { Kabupaten Tanah Datar (luhak } \\
\text { Tanah Datar) }\end{array}$} & \multicolumn{2}{c|}{$\begin{array}{c}\text { Kabupaten Lima Puluh Kota } \\
\text { (Luhak Limo Puluah Koto) }\end{array}$} \\
\hline Nama Nagari & Jumlah & Nama Nagari & Jumlah & Nama Nagari & Jumlah \\
\hline Lasi & 6 unit & Pandai Sikek & 0 unit & Simalanggang & 1 unit \\
\hline Ampek Angkek & 4 unit & Pagaruyung & 21 unit & Mudiak & 7 unit \\
\hline Kamang Magek & 2 unit & Sungayang & 14 unit & Danguang- & 3 unit \\
\hline Sungai Pua & 14 unit & Minangbakabau & 2 unit & Suliki & 12 unit
\end{tabular}

This condition might not be happen if this art is protected and preserved because it is one of traditional knowledge and the expression of Minangkabau's indigenous people. Because of the extinction of the Rumah Gadang's carved, this research aims to investigate some factors of the extinction itself.

\section{Method}

The method of this research is qualitative in the form of a case study of phenomenology. The informants of this research are penghulu adat (the leader of a tribe), carvers, people who understand about the carving art, culture observers, and tourism departments. The total of the informants is 64 people. An observation and in-depth interview are used to collect the data of this research. The locations of getting the data are Kabupaten Agam, Tanah Datar, and Lima Puluh Kota where the carving art of Rumah Gadang still exist.

\section{Findings and Discussion}

After collecting and analyzing the data, it is got that there are three factors that causes the extinction of traditional knowledge in Minangkabau's Rumah Gadang carved.

\subsection{People's views are changing}

The first factors that causes the extinction of Rumah Gadang carved knowledge is the changing of people's views. The people tend to think modernly. This kind of view makes 
the culture value hard to be protected. The data shows that the Minangkabau people who live today assess their life by the social status. However, long time ago Minangkabau people lived homogeny without considering the social status because they thought that they have same status of Allah's creation. They also had a statement "duduak samo randah... tagak samo tinggi..." (There is no discrimination between one and another in the society). However, Minangkabau people today view live by considering education level, job, and other social status. It is supported by Soekanto (2006) says that social status is one of characteristics of modern people. This think makes people care more about their formal educations, and jobs that can place them in the top of the social status. Hence, the traditional knowledge such as the carved art of Rumah Gadang left behind because it is not as the requirement to get the social status. Another effect of this condition is the number of cavers who transfer the knowledge is very limited. It can be seen from the following table:

TABLE 2: Custodian's names Rumah Gadang carve in Kabupaten Lima Puluh Kota.

\begin{tabular}{|c|c|c|c|c|}
\hline No & Place & Gelar Datuak & Tribe & Note \\
\hline 1 & $\begin{array}{l}\text { Nagari Mudiak and } \\
\text { Danguang-Danguang }\end{array}$ & $\begin{array}{l}\text { Datuak Parpatiah } \\
\text { Datuak Panghulu Basa } \\
\text { Datuak Marajo Basa } \\
\text { Datuak Paduko Indo }\end{array}$ & $\begin{array}{l}\text { Caniago } \\
\text { Tanjuang } \\
\text { Caniago } \\
\text { Caniago }\end{array}$ & $\begin{array}{l}\text { extinct } \\
\text { extinct } \\
\text { not interested by the } \\
\text { people }\end{array}$ \\
\hline 2 & Nagari Tanjuang Pati & $\begin{array}{l}\text { Datuak Marajo } \\
\text { Datuak rajo Indo } \\
\text { Datuak Permato Alam }\end{array}$ & $\begin{array}{l}\text { Pitopang } \\
\text { Kutianyie } \\
\text { Koto }\end{array}$ & $\begin{array}{l}\text { extinct } \\
\text { extinct } \\
\text { not interested by the } \\
\text { people }\end{array}$ \\
\hline 3 & $\begin{array}{l}\text { Nagari Simalanggang } \\
\text { and koto Baru }\end{array}$ & $\begin{array}{l}\text { Datuak Panghulu Bosa } \\
\text { Datuak Indo } \\
\text { Datuak Malano Indo } \\
\text { Datuak Damuanso }\end{array}$ & $\begin{array}{l}\text { Pitopang } \\
\text { Kutianyie } \\
\text { Pitopang } \\
\text { Pitopang }\end{array}$ & $\begin{array}{l}\text { Not interested by } \\
\text { people because it is } \\
\text { old }\end{array}$ \\
\hline 4 & Nagari Suliki & $\begin{array}{l}\text { Datuak Bosa } \\
\text { Datuak Malano } \\
\text { Datuak Bandaro Sati } \\
\text { Datuak Paduko Alam }\end{array}$ & $\begin{array}{l}\text { Pitopang } \\
\text { Piliang } \\
\text { Melayu } \\
\text { Caniago }\end{array}$ & $\begin{array}{l}\text { extinct } \\
\text { extinct } \\
\text { extinct } \\
\text { not interested by the } \\
\text { people }\end{array}$ \\
\hline
\end{tabular}

The previous table explains that carvers who have ability in producing Minangkabau carves are extinct. It is happen because there is no interest of people to learn this knowledge. They think that it is ancient and cannot help them to raise their social status. On the other hand, the carvers do not have sons or nephews that can be taught Minangkabau carve.

\subsection{Muatan lokal subject is not taught in the formal education}

Muatan lokal had been had in formal education as one of subjects that teaches about culture. It is proven by SK Kemendikbud No. 060/U/1993. Tirtaraharja and La Sulo (2005) 
explains that Muatan Lokal is an education program which it's content and media relate with nature, social, and cultural environment of each local area or province. West Sumatera is one of the provinces that develops the sharpen curriculum of Muatan Lokal. One of the topics is the Natural Culture of Minangkabau or in Bahasa called as Budaya Alam Minangkabau (BAM). BAM tells about meaning of folklores had by Minangkabau culture besides learning how to make Minangkabau carve. Therefore, BAM becomes one of forums to preserve the culture (Agustina, 2007).

Actually, there are four functions of BAM (Satya, 2004). First, it gives a basic knowledge that BAM is as national culture to the students. Second, it builds students' belief that Minangkabau culture is as national culture. Third, it shows how the values of Minangkabau culture are used in people daily life. Last, it helps students to learn, investigate, preserve, and develop the knowledge of Minangkabau culture as national culture. It is hope that students apply the culture in their life. For example, the students can not only produce Minangkabau carve but also know the story and meaning of the shape that is carved. Indirectly BAM has preserved the traditional knowledge of Minangkabau (Dinas Kebudayaan dan Pendidikan Sumatera Barat, 1997).

However, in 2018, BAM is not taught anymore. It is replaced by another version of Muatan Lokal based on Kurikulum 2013. Kementrian Pendidikan dan Kebudayaan Direktoran Jenderal Pendidikan Dasar dan Menengah (2015), this new version is explaining about art (traditional games, dances, music, batik), workshop (traditional food, craft carving, leather crafts, weaving crafts), physical education, sport and health (pencak silat, sepak takraw), languages (traditional language and foreign language), and technology (computer and automotive). The content of this curriculum is tailored to the potential and the uniqueness of the region. Based on the researchers' analysis, there is no content that presents the traditional knowledge in the Handbook of Muatan Lokal for Elementary and Middle School. The content of that book only focuses on physical culture such as traditional food, crafts, dances, and others. Furthermore, the Curriculum of Muatan Lokal that is based on Kurikulum 2013 is not already developed by the government of West Sumatera. Consequently, BAM is disappeared (Agregasi Antara, 2017). 


\subsection{The regulation of protection of traditional knowledge has not been clear}

In Indonesia, traditional knowledge is included in an intellectual property which is from ideas, thought, or people's invention of a country. The problem is the traditional knowledge is always connected with Intellectual Property Right (IPR). Meanwhile, the characteristics of the traditional knowledge which are communal, concrete, cash, and open is contrary to the concept of IPR. The traditional knowledge is collective and owned by all indigenous people. It is not owned by an individual. On the other hand, the concept of IPR refers to Trade Related Intellectual Property Rights Agreement (TRIP's) that its orientation is capitalistic concept that is adopted by developed countries. This concept focuses on the concept of economic profit of an individual (Stiglitz, 2007), because of that the system of IPR cannot be implemented for Indonesian Traditional Knowledge which is owned by communal.

Moreover, the indigenous people think that the traditional knowledge is as public right. It means that the people do not object if their products are used, imitated commercially by other people. However, this situation can lead the misappropriation (Sardjono, 2006) that is done by the other side. They modify the traditional knowledge and get the IPR. It makes the original owner of the traditional knowledge incur losses.

Those cases are happen because the regulations of the protection of the traditional knowledge are still weak. Actually, there is an act about national copyright has been had since 1982, Article 10 Number 6 . This regulation is continued by Article 10 Act Number 19, 2002 about Copyright (Kusumadara, 2011). Last, it is Article 13 Act of Copyright 2014. However, those acts are not enough to define the IPR explicitly and cannot protect the traditional knowledge. There is no special law which concerns on traditional knowledge in Indonesia until now.

\section{Conclusions and Suggestions}

There are three factors of the extinction of Minangkabau traditional knowledge. First, there is a thinking movement of people to think modernly. The Minangkabau people today leave the traditional knowledge because they think that it is old. Moreover, people think that formal education is the primary requirement to get social status and future success. Second, The Natural of Minangkabau Culture, the subject of Muatan Lokal, is not taught anymore in the formal education. In addition, the new version of this curriculum 
is not already done by the government. Last, the regulations to protect the traditional knowledge are not clear enough.

\section{References}

[1] Agustina. (2007). Pembelajaran Budaya Alam Minangkabau (BAM) sebagai Wadah Pelestarian Kearifan Lokal: Harapan dan Kenyataan, Jurnal Bahasa dan Seni, Vol 13 No 1 Tahun 2012, Universitas Negeri Padang, p.25

[2] Agregasi Antara. (2017, April 17). 600 Guru BAM tidak lagi Mengajar, Okezone News, retrieved from https://news.okezone.com/read/2017/03/18/65/1646130/duh600-guru-budaya-alam-minangkabau-tak-lagi-mengajar.

[3] Dinas Kebudyaan dan Pendidikan Smatera Barat. (1997). GBPP Budaya Alam Minangkabau kelas II SMP Caturwulan II.

[4] Kementrian Pendidikan dan Kebudayaan Direktoran Jendral Pendidikan Dasar dan Menengah. (2015). Panduan Teknis Pengembangan Muatan Lokal SD dan SMP, Direktorat Pembinaan Sekolah Dasar, Jakarta, p.3

[5] Kusumadara, Afifah. (2011). Pemeliharaan dan Pelestarian Pengetahuan Tradisional dan Ekspresi Budaya Tradisional Indonesia: Perlindungan Hak Kekayaan Intelektual dan Non-Hak Kekayaan Intelektual, Jurnal, p. 22

[6] Sardjono, (2010). Agus, Hak Kekayaan Intelektual dan Pengetahuan Tradisional, Penerbit PT Alumni, Bandung, p. 11.

[7] Satya, Gayatri. (2004). Pengajaran Muatan Lokal di Sumatera Barat dan dilemanya, Jurnal IImu Budaya, Vol 5 No. 2 Tahun 2009, Universitas Andalas, Padang, p.17

[8] Soekanto, Soerjono. (2006). Sosiologi Suatu Pengantar. Jakarta: PT. Raja Grafindo Persada.

[9] Stiglitz, Joseph E. (2007). Making Globalization Work: Menyiasati Globalisasi menuju Dunia yang Lebih Adil [Making Globalization Work], diterjemahkan oleh Endrijani Azwaldi (Badung: Mizan Pustaka, 2007), p. 432.

[10] Tirtaraharja and La Sulo. (2005). Pengantar Pendidikan. Jakarta: Rineka Cipta. 